\title{
FACTORS AFFECTING THE PROFITABILITY OF POULTRY EGG PRODUCTION IN SOUTHWEST NIGERIA: AN APPLICATION OF QUANTILE REGRESSION
}

\author{
Sina Basil JOHNSON *I (D), Taiwo E. MAFIMISEBI ${ }^{2}$, Adegoyega E. OGUNTADE ${ }^{2}$, Ojuotimi E. \\ MAFIMISEBI $^{1}$
}

\author{
Address: \\ ${ }^{1}$ Rufus Giwa Polytechnic, Owo, Faculty of Agricultural Technology, Department of Agricultural Extension \& \\ Management, P. M. B 1019, Ondo State, Nigeria \\ ${ }^{2}$ The Federal University of Technology, Akure, School of Agriculture \& Agricultural Technology, Department of \\ Agricultural \& Resource Economics, P. M. B 704, Ondo State, Nigeria \\ * Corresponding Author: johnsonbasil95@ yahoo.com
}

\begin{abstract}
This study investigated the key factors affecting the profitability of poultry egg production in Southwest, Nigeria. A multi-stage sampling procedure was employed to select 360 egg farmers using a structured questionnaire. Data collected were analysed using descriptive and inferential statistics. Descriptive statistics showed that the mean age of egg farmers was 45 years. Majority (68.3\%) of the farmers were male households. Over half $(57.8 \%)$ of the farmers had tertiary school education and majority $(85.0 \%)$ of them were married. The distribution of flock size showed that majority of the farmers was medium-scale poultry farmers. The result revealed that egg production is profitable. Results of the quantile regression revealed that farmer's age, farm size, price per crate of egg, cost of drugs as well as farm location had positive significant impacts on farm income at various quantiles. However, education, experience and household size, costs of labour, feed and day-old-chicks were identified to have negative but significant impact on farm income across the quantiles.
\end{abstract}

Keywords: Quantile regression, Poultry Egg, Farm income

JEL: C14, C21, Q12

\section{INTRODUCTION}

Agriculture is a major non-oil sector, contributing significantly to the Nigerian economy. In 2018, this sector contributed about $26.2 \%$ to the overall gross domestic product (GDP) in real terms. Livestock industry is one of the subsectors in agriculture, employing over 25 million of Nigeria's population directly and indirectly specifically in poultry industry (NBS, 2018). Livestock contributed $6 \%$ to $8 \%$ of national GDP (ASL, 2018). It is a good weapon to fight poverty and unemployment. Okunmadewa, (1999) asserted that livestock are instruments that can turn around the socioeconomic life of the rural people especially in the developing countries. It is possible to rear them in small, medium and large scale. Nigerian livestock consists of poultry, cattle, pig, sheep and goat. NASS (2011) revealed that livestock population in Nigeria consists of 19.5 million cattle, 41.3 million sheep, 72.5 million goats, 7.1 million pigs, 145 million poultry, 11.6 million ducks, 28,000 camels, 1.2 million turkey, and 974,499 donkeys in 2011. Poultry distribution accounted for almost half of the total livestock reared in Nigeria.

The contribution of poultry farming to livestock production and gross domestic product was 58.2\% (Amos, 2006). There are many gainful opportunities in the poultry industry. Poultry provides a diversity of business interests which include egg and meat production, hatchery and inputs providers and this in turn provides additional income to the family (Oluyemi and Roberts, 1979; Laseinde, 1982).

The supply of poultry eggs and meat in Nigeria over the years has been on the increase in spite of challenges but the proportion of its increases still falls short of desire. Major factors responsible for low production in poultry industry as revealed in Alabi and Isah (2002) are low capital base, lack of equity, infection with diseases and parasites, high cost of feed and use of poor quality of dayold chicks. The high costs of maize and soybeans have gone beyond the means of most poultry farmers (Sahel, 2015). The quality of soybean and corn produced in Nigeria is low and inadequate to meet the needs of local feed millers. Fueling the input crisis, the high cost of imported feed has forced majority of the farmers to improvise and reformulate poultry feeds with low quality materials such as peanut cake, cotton seed and palm kernel meal (World Poultry, 2013). Therefore, high cost of inputs (e. $\mathrm{g}$ feeds) is a major challenge in poultry industry because feeds purchase, for example consumed as much as $70 \%$ of the cost of production which has even led to a large reduction in the number of commercial poultry farmers especially the small-scale ones who could not withstand production of eggs at high cost Adebiyi, 2000; Ashagidigbi, Sulaimon and Adesiyan, 2011).

The high cost of inputs would definitely affect the level of income among poultry egg farmers. Nigerian 
government in the past and even recently has come up with many programs that geared towards abating the problem of high cost of inputs in poultry industry. Some of these programs include Micro-Credit Scheme for Livestock Production, Community-Based Agricultural and Rural Development Project (ADF, 2003) and National Egg Production (NEGPRO). NEGPRO is the Federal Government of Nigeria initiative designed to create more job opportunities, remove hunger and alleviate poverty. The program is aimed at giving accredited farmers an enabling environment to access a 25 billion set aside by the Central Bank of Nigeria through Bank of Industry (BOI). The scheme also aimed at increasing the output of egg production to 50 million table egg daily by 2018 . Similar effort in this direction is the African Chicken Genetic Gain in Nigeria (ACGG-NG) launched in 2015 as collaborative research agreement between the International Livestock Research Institute (ILRI) and Obafemi Awolowo University (OAU) with a major objective of conducting baseline survey on the status of smallholder chicken (SHC) farmers across the agroecological zone in the country and to determine genetically improved chicken preferred by smallholder chicken producers. These programs are not heard of again because they are politically motivated and ill-funded.

The present study is therefore undertaken to investigate the factors affecting farm income among poultry egg farmers in Southwest, Nigeria. Specifically, the study computed the cost and returns associated with poultry egg farming and identified factors influencing farmincome among egg farmers in the study area. Several studies have been carried out on economic analysis of poultry egg farming before now but majority of them focused on efficiency of resource-use in poultry egg farming with little or no attention on factors determining the distribution of income among egg farmers in the study area. For examples, Ojo (2003) employed stochastic frontier production function to determine technical efficiency of poultry egg production in Nigeria. Amos (2006) carried out the analysis of backyard poultry production in Ondo State, Nigeria, using multiple regressions. Result from the study showed that the cost of feeding and veterinary cost were major factors affecting production poultry in the study area. In a similar study by Emokaro and Emokpae (2014) stochastic frontier production function was also used to investigate the technical efficiency and production elasticity of broilers in Edo State, Nigeria. Results of their study showed that $82.9 \%$ of broiler farmers had technical efficiency ranging between 0.81 and above. The estimated gamma coefficient was 0.74 , indicating that a technical inefficiency exists in broiler production in the study area. Result further revealed that broiler farmers in the study area operated within the stage 1 of the production function based on the production elasticity of 1.2 estimated in the study.

Majority of past literature has concentrated on average income accruing to egg farmers. The assumption of homogeneity in the income earned among poultry egg farmer using mean may be grossly inadequate. However, policy measures taken according to these results are not likely to be equally effective for all farmers who are into egg production. It is, therefore, imperative to consider the heterogeneity among the population of egg farmers. The results from this study will provide useful information for policy makers.

\section{DATA AND METHODS}

\section{Study Area}

The study was carried out in Southwest, Nigeria. Southwest is one of the six geo-political zones in Nigeria which comprises of six States that include Lagos, Ogun, Ondo, Ekiti, Osun and Oyo. The total population as at 2006 census was 28,767,752 (NPC, 2006). The region enjoys tropical climate with two distinct seasons, the rainy season (April-October) and the dry season (NovemberMarch). The study area lies between longitude $2^{0} 31^{\prime}$ and $6^{0} 00^{\prime} \mathrm{E}$ and latitude $6^{0} 21^{\prime}$ and $8^{0} 37^{\prime} \mathrm{N}$ with a total land area of $77,818 \mathrm{~km}^{2}$ (Agboola, 1979). Southwest is bounded in the east by Edo and Delta States, in the North by Kwara and Kogi States, in the West by the Republic of Benin and in the South by the Gulf of Guinea. The wet season is associated with the Southwest monsoon wind from the Atlantic Ocean while the dry season is associated with the northeast trade wind from the Sahara Desert.

Agriculture is one of the major occupations of the people in the study area. Livestock farming is a popular business among the people. They rear animals like goat, sheep, pig and poultry keeping. Poultry management is common in both the rural, peri-urban and urban areas of Southwest, Nigeria. The area is blessed with rivers which gives them diverse opportunities like transportation, fishing and lumbering.

A multi-stage sampling procedure was used to select the respondents. Data were collected from 360 egg farmers in the study area through a structured questionnaire and interview schedule. In the first stage, three out of six States in Southwest that are highly prominent in egg production were purposively selected. The selected States include Lagos, Oyo and Ogun (NBS, 2006). In the second stage, two Local Government Areas (LGAs) from each of the State that are highly prominent in layers production were also purposively selected using the list of members of Poultry Association of Nigeria (PAN) as a guide. The Local Government Areas (LGAs) selected were Shagamu and Odeda in Ogun State, Alimosho and Ojo in Lagos State and Afijio and Oyo West in Oyo State.

In the third stage, sixty (60) egg farmers were randomly selected from each of the LGAs of the States sampled, giving one hundred and twenty (120) poultry egg farmers per State. Finally, a pool of three hundred and sixty (360) egg farmers were randomly sampled from the three States and analysed in this study.

\section{Net Income Estimation}

Profitability in egg production was computed using net income estimation method to ascertain profit accruing to the poultry egg producers in the study area. This can be specified as the Eq. 1-3.

$$
\begin{aligned}
& \mathrm{NI}_{\mathrm{i}}=\mathrm{TR}_{\mathrm{i}}-\mathrm{TC}_{\mathrm{i}} \\
& \mathrm{TR}_{\mathrm{i}}=\mathrm{P}_{\mathrm{i}} * \mathrm{Q}_{\mathrm{i}} \\
& \mathrm{TC}_{\mathrm{i}}=\mathrm{TFC}_{\mathrm{i}}+\mathrm{TVC}_{\mathrm{i}}
\end{aligned}
$$


Therefore,

$\mathrm{NI}_{\mathrm{i}}=\mathrm{P}_{\mathrm{i}} * \mathrm{Q}_{\mathrm{i}}-\left(\mathrm{TFC}_{\mathrm{i}}+\mathrm{TVC}_{\mathrm{i}}\right)$

Where:

$\mathrm{NI}_{\mathrm{i}}$ Nnet income accrued to ith farmer on sale of egg $(\mathrm{N})$; $\mathrm{TR}_{\mathrm{i}}$ Total revenue realised from the sale of eggs by ith farmer ( $)$;

$\mathrm{TVC}_{\mathrm{i}}$ Total variable cost incurred on production of eggs by ith farmer ( $)$;

$\mathrm{Q}_{\mathrm{i}}$ Total quantity of eggs produced by ith farmer (crate)

$P_{i}$ Current price per unit of output ( $)$;

$\mathrm{TFC}_{\mathrm{i}}$ Total fixed cost incurred by ith farmer (

\section{Quantile Regression Model}

Given the Ordinary Least Square model as Eq. 5.

$$
Y_{i}=\beta_{0}+\beta_{1} X_{1}+\beta_{2} X_{2}+\beta_{n} X_{n}+\varepsilon_{i}
$$

With $\varepsilon_{i}$ independently and identically distributed with mean zero and constant variance. Given a random variable with a probability

$F(y)=\mathrm{P}(\mathrm{Y} \leq \mathrm{y})$

As opined by Koenker and Bassett (1982), the $\tau$ th quantile of $\mathrm{Y}$ is given as

$\mathrm{Q}_{\mathrm{y}}(\tau)=\{\inf (\mathrm{y}=\mathrm{F}(\mathrm{y}) \geq \tau\}$ where $\tau \in[0,1]$. Hence, the conditional quantile $Q_{(\tau / x)}$ is the inverse of the conditional function of the response variables.

Therefore, the quantile function Equation 5 can be written as Eq. 6.

$$
\begin{aligned}
& Y_{i}=\beta_{0}(\tau)+\beta_{1}(\tau) X_{1}+\beta_{2}(\tau) X_{2}+\cdots .+\beta_{n}(\tau) X_{n}+ \\
& \varepsilon_{i}
\end{aligned}
$$

The conditional quantile function is given by Eq. 7 .

$$
Q_{(\tau / \varepsilon)}=\beta_{0}(\tau)+\beta_{1}(\tau) X_{1}+\beta_{2}(\tau) X_{2}+
$$$$
\cdots .+\beta_{n}(\tau) X_{n}+u_{i}
$$

$\varphi_{t}=Q_{(\tau)} \varepsilon_{t}$ is identically distributed with mean zero and variance one. This can simply be written as Eq. 8 .

$Q_{y i}(\tau / \varepsilon)=X^{T}{ }_{i} \beta_{i}(\tau)$

Where:

$X=\left(1, X_{0} \ldots \ldots \ldots . X_{n}\right)^{T}$
The conditional cumulative probabilities of $\left(\mathrm{Y}_{\mathrm{i}}\right)$, is given by Eq.10.

$\operatorname{Pr}\left(\mathrm{Y}_{\mathrm{i}} \leq \mathrm{q}(\mathrm{Xi}) / \mathrm{Xi}=\mathrm{x}=\tau\right.$

We solve the minimization problem

$$
\mathrm{E}\left(\mid \mathrm{Y}_{\mathrm{i}}-\mathrm{q}\left(\underset{f \in L(u)}{(\mathrm{Xi}) \tau \mid \mathrm{X}_{\mathrm{i}}}=\mathrm{x}\right) \quad \min E\left(\left|Y_{\mathrm{i}}-f(X i)\right| \tau \mid X_{\mathrm{i}}=x\right)\right.
$$

The $\tau$ th quantile regression estimator $\widehat{\beta}_{\mathrm{i}}$ that minimizes over $\beta_{\tau}$ the objective function is given as the Eq. 12 .

$Q\left(\beta_{\tau}\right)=\sum_{y_{\mathrm{i}}>X_{\mathrm{i}} \beta \tau}^{n}(\tau)\left|Y_{\mathrm{i}}-X_{\mathrm{i}}^{T}\right|+\sum_{y_{\mathrm{i}}<X_{\mathrm{i}} \beta \tau}^{n}(1-\tau) \mid Y_{\mathrm{i}}-$ $X_{\mathrm{i}}^{T} \beta \tau$

Where: $\tau\left|e_{i}\right|$ and $(1-\tau)\left|e_{i}\right|$ are called the asymmetric penalties for under prediction and over prediction and $0<$ $\tau<1$ (Nyantakyi, Peiris and Gunaratne, 2015).

To evaluate the effects of socio-demographic variables and poultry specific attributes on farmincome of the poultry egg farmers, quantile regression was used in this study based on several advantages of the model over Ordinary Least Square method (OLS) which include ability to capture outlier when distribution of data skews to one side and some are far away from the mean, Again, quantile regression can help to address the problem of heterogeneity in data. It looks beyond locating the central location of data. Looking exclusively on changes in the mean may underestimate, overestimate, or even fail to distinguish real non-zero changes in heterogeneous distributions (Cade, Terrell and Schroeder, 1999). The explicit functional form can be stated as Eq. 13 .

$Q \tau(Y / X)=x)=X^{T}(\tau) 0<\tau<1$

Where:

$Y$ Average total income earned per annum by ith farmer from egg production;

$\mathrm{X}_{1}-\mathrm{X}_{\mathrm{n}}$ Socio-demographic characteristics of farmers and poultry specific attributes in egg production;

$\mathrm{B} \tau$ marginal change in the $\tau$ th quantile due to marginal change in $\mathrm{X}$.

The dependent variable and independent variables used in this study are presented in Table 1 .

Table 1: Description and Measurement of Variables used in Quantile Regressions Model

\begin{tabular}{lllc}
\hline Variable & Name & Measurement & A priori expectations \\
\hline $\mathrm{Y}_{\mathrm{i}}$ & Average Net income & Naira & - \\
$\mathrm{X}_{1}$ & Age & Years since birth & + \\
$\mathrm{X}_{2}$ & Education & Years of schooling & - \\
$\mathrm{X}_{3}$ & Household size & Number of persons in household & + \\
$\mathrm{X}_{4}$ & Experience & Years in egg production & + \\
$\mathrm{X}_{5}$ & Farm size & Area in m & \\
$\mathrm{X}_{6}$ & Price of egg & N/crate of egg & + \\
$\mathrm{X}_{7}$ & Cost of Labour & N/hour worked & - \\
$\mathrm{X}_{8}$ & Cost of Feed & N/kilogramme & - \\
$\mathrm{X}_{9}$ & Cost of day-old-chicks & N/Bird & - \\
$\mathrm{X}_{10}$ & Cost of Drugs & N/Dose used & - \\
$\mathrm{D}_{2 \mathrm{i}}$ & Ogun State & If Poultry farmer is in Ogun $=1,0$ otherwise & \pm \\
$\mathrm{D}_{3 \mathrm{i}}$ & Oyo State & If Poultry farmer is in Oyo $=1,0$ otherwise & \pm \\
\hline
\end{tabular}




\section{RESULTS AND DISCUSSION}

Socioeconomic Characteristics of Poultry Egg Farmers

The socio-economic characteristics of egg farmers in the study area are presented in Table 2 . The mean age of the egg farmers was 45 years, implying that the farmers were still economically active. The farmers will be able to cope with the stress and rigour associated with poultry farm operations. This finding is in line with the findings of Ojo (2003) who found an average of 45 years for egg farmers in Oyo State, Nigeria. Majority (68.3\%) of the farmers were male households with female households accounting for $31.7 \%$. The mean poultry farming experience was 12 years, suggesting that farmers would be able to take reasonable decisions based on their years of experience in poultry management. This finding is in line with the study conducted by Adeyonu et al., (2016) who reported 13 years of mean experience of poultry egg farmers in Oyo State. The mean household size was 5 persons per household. The mean household size estimated in this study agreed with the findings by Emokaro and Emokpae (2014) who reported that majority of poultry egg farmers in Edo State, had a family size range between 1and 6 persons.

Table 2: Socioeconomic Characteristics of Poultry Egg Farmers

\begin{tabular}{lrr}
\hline Variable & Frequency & $\begin{array}{l}\text { Percentage } \\
(\%)\end{array}$ \\
\hline Age in years & & \\
$\leq 30$ & 52 & 14.4 \\
$31-45$ & 150 & 41.7 \\
$46-60$ & 118 & 32.8 \\
$>60$ & 40 & 11.1 \\
Mean & $44.53 \pm 11.8$ & \\
Gender & & \\
Male & 246 & 68.3 \\
Female & 114 & 31.7 \\
Poultry experience & & \\
$\leq 10$ & 42 & 11.7 \\
$11-20$ & 228 & 63.3 \\
$21-30$ & 82 & 22.8 \\
$>30$ & 08 & 2.2 \\
Mean & 11.99 & \\
Household size & & \\
$\leq 5$ & 274 & 76.1 \\
6-10 & 84 & 23.3 \\
$>10$ & 02 & 0.6 \\
Mean & 5.0 & \\
Education & & \\
No formal school & 14 & 3.9 \\
education & & \\
Primary school education & 22 & 6.1 \\
Secondary school & 116 & 32.4 \\
education & & \\
Tertiary school education & 208 & 57.8 \\
Marital status & & \\
Single & 54 & 15.0 \\
Married & 306 & 85.0 \\
Total & 360 & 100.0 \\
\hline Souc: Fiel & & \\
\hline
\end{tabular}

Source: Field survey, 2018
Over half of the sampled farmers (57.8\%) had tertiary school education. About 3.9\% of the farmers were not educated. Thus, $96.1 \%$ of the poultry egg farmers had formal school education. This result here agreed with the findings of Adeyonu et al. (2016) that over 50\% of poultry farmers in Oyo State had tertiary school education. The study further unveiled it that majority $(85.0 \%)$ were married while about $15.0 \%$ were yet to marry. Majority $(70.0 \%)$ of the farmers had access to extension services in the surveyed area, indicating that the farmers would be highly informed and aware of poultry egg related innovations

\section{Flock Size}

Table 3 presented the distribution of poultry egg farmers by flock size. The mean flock size was 2003.19. This structure according to the classification of Omotosho and Oladele (1988); Ojo (2003) and Adene and Oguntade (2006) showed majority of poultry egg farms in the surveyed area fall within the range of medium-scale farming.

Table 3: Distribution of Respondents by Flock Size

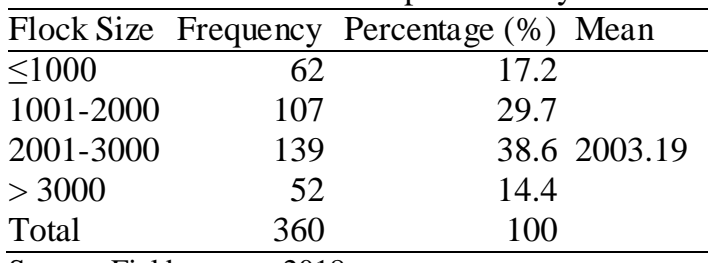

Source: Field survey, 2018

\section{Cost and Returns Structure in Poultry Egg Production per 2003 birds}

The profitability analysis of poultry egg production using net income estimation is presented and discussed as follows. Table 4 presents the cost and returns in poultry egg farming in the study area. The depreciation on TFC incurred on fixed items was $\$ 239,691.32$ representing $12.0 \%$ of the TC. The average value of the TVC was $\$ 1,750,502.9$ per annum, and this value accounted for about $88.0 \%$ of the TC. Evaluation of the TVC reveals that the cost of labour, day-old-chicks, medications and feeds accounted for a pool of $84.6 \%$ of the TC of egg production. The table reveals that the four major inputs in egg production are feeds, labour, DOC and medications. These variables inputs gulp more than half $(85.0 \%)$ of the TC of production in egg faming.

It was also observed that about $53.3 \%$ of the $\mathrm{TC}$ went for feeds making it the highest cost incurred on variable items in the production of egg. This result agrees in part with findings from a number of studies on economic analysis of poultry egg farmers. For example, the findings in separate studies carried out by Adepoju (2008); Afolami; Aladejebi and Okojie (2013) on poultry egg farming in Nigeria showed that feed had the largest cost share of the TC of production. On the other hand, the result on proportion of expenditure that went for feeds was lower than the one reported in the aforementioned literature. This also implies that some of the poultry egg farmers are likely to be new entrants in the industry. As new entrants, they are yet to spread or reduce the average fixed costs of their farms. 
Table 4: Cost and Returns Structure in Poultry Egg Production per 2003 Birds

\begin{tabular}{|c|c|c|}
\hline Item & Mean value (A/year) & Percentage $(\%)$ \\
\hline \multicolumn{3}{|l|}{ Variable cost Items } \\
\hline Labor & $338,197.00$ & 16.99 \\
\hline Day-old-chicks & $199,129.80$ & 10.01 \\
\hline Medications & $85,278.00$ & 4.28 \\
\hline Feeds & $1,061,393.50$ & 53.33 \\
\hline Transport & $8,833.10$ & 0.44 \\
\hline Electricity & $3,633.30$ & 0.18 \\
\hline Fuel & $5,674.10$ & 0.29 \\
\hline Water & $2,671.20$ & 0.13 \\
\hline Saw-dust & $1,319.90$ & 0.07 \\
\hline Repairs and Maintenance & $5,757.04$ & 0.29 \\
\hline Veterinary Charges & $35,338.30$ & 1.78 \\
\hline Disinfectants & $3,277.60$ & 0.16 \\
\hline Total Variable Cost (TVC) & $1,750,502.90$ & 87.95 \\
\hline \multicolumn{3}{|l|}{ Fixed Cost Items } \\
\hline Depreciated cost of vehicles & $54,330.20$ & 2.73 \\
\hline Depreciated cost of buildings & $76,012.30$ & 3.82 \\
\hline Depreciated cost of cages & $5,924.50$ & 0.30 \\
\hline Depreciated cost of shovels & 92.30 & 0.01 \\
\hline Depreciated cost of empty crates & 558.60 & 0.03 \\
\hline Depreciated cost of land & $100,489.90$ & 5.05 \\
\hline Depreciated cost of feeders & $1,086.80$ & 0.05 \\
\hline Depreciated cost of drinkers & $1,196.70$ & 0.06 \\
\hline Total Fixed Cost (TFC) & $239,691.32$ & 12.05 \\
\hline Total Cost $(\mathrm{TC})=\mathrm{TFC}+\mathrm{TVC}$ & $2,990,194.22$ & 100.0 \\
\hline Revenue from egg sold & $3,633,093.25$ & 74.92 \\
\hline Revenue from spent layers sold & $1,216,215.31$ & 25.08 \\
\hline Total Revenue (TR) & $4,849,308.56$ & 100.0 \\
\hline Net Income NI=TR-TC & $2,859,114.35$ & \\
\hline Returns on Investment $(\mathrm{ROI})=\mathrm{NI} / \mathrm{TC}$ & 1.44 & \\
\hline Net profit Ratio $=$ NI/TR & 0.59 & \\
\hline
\end{tabular}

Source: Field Survey, 2018

The result also reveals that costs of the following variable items; transport, electricity, fuel, water, saw-dust, disinfectants, repairs and maintenance and veterinary charges accounted for $3.3 \%$ altogether.

For the revenue aspect, the mean value of the total sales on eggs and spent layer was $44,849,308$ as the value of eggs alone contributed $74.9 \%$ to the total revenue while value of spent layers accounted for about $25.1 \%$ of the total revenue. This result implies that egg is the major revenue contributor in poultry egg production. The result of profitability of egg business showed that it was profitable in the study area, given a net income of $\$ 2,859,114.35$. The profitability ratios computed in this study revealed that the returns on investment (ROI) was 1.44 which implied that for every 1 invested in poultry egg farming, a profit worth of 0.44 will be accrued to the farmer. Similarly, a net income ratio of 0.59 was computed, implying that 59 kobo will be realised as gain on every 1 expended on poultry egg farming. The profitability ratios reported here are all higher than any of the agricultural interest rate of $10 \%$ for the Bank of Agriculture (BOA) and Bank of Industry (BOI). The result here supports the findings of Afolami et al. (2013), Evbuomwan (2005) that egg production is a profitable venture.
Factors Influencing Farm Income among Egg Farmers

Table 5 shows the coefficients and t-values of quantile regression and Ordinary Least Square (OLS) results. The first three columns displayed the results of various quantile regression models considered and OLS regression model occupied the fourth column for comparison. To judge the predictability of various models in this study, economic theory and econometric criteria were employed which include the F-statistics, plausibility of variables signs, number of significant variables and adjusted R-squared of individual model. The F-statistics was statistically significant at the $1 \%$ level, which implies that all the explanatory variables in the model jointly exerted a significant impact on farm income realised from egg.

Looking at the various quantile models, the pseudo $\mathrm{R}^{2}$ at $25^{\text {th }}, 50^{\text {th }}$ and $75^{\text {th }}$ quantiles, were $54 \%, 59 \%$ and $62 \%$, respectively. For example, at 25 th percentile, about $54 \%$ of the variation in the net income of egg farmers was explained by all the independent variables in the model. Similarly, 59\% of variation in the dependent variable was also explained by all the explanatory variables in the model at median quantile. At $75^{\text {th }}$ quantile, the proportion of variation of income explained by the entire independent variables was $62 \%$. 
Table 5: Parameter Estimates of the Quantile Regression V OLS

\begin{tabular}{|c|c|c|c|c|c|c|c|c|}
\hline$\overline{\text { Quantile }}$ & $\tau=0.25$ & & $\tau=0.5$ & & $\tau=0.75$ & & OLS & \\
\hline Variable & Coeff & t-ratio & Coeff & t-ratio & Coeff. & t-ratio & Coeff. & t-ratio \\
\hline Constant & -9.8775 & -0.82 & $-95.8487 * *$ & -2.63 & $-201.6141 * * *$ & -3.91 & $-258.775^{* *}$ & -2.38 \\
\hline Age & $0.7888 * * *$ & 164.68 & $1.2007 * * *$ & 79.78 & $1.4080 * * *$ & 53.13 & $1.9187 * * *$ & 43.33 \\
\hline Experience & $-0.1907 * * *$ & -19.85 & $-0.4383 * * *$ & -17.53 & $-0.5666 * * *$ & -13.73 & $-0.6320 * * *$ & -8.52 \\
\hline Household size & $-0.4329 * * *$ & -8.51 & -0.1143 & -0.91 & 0.1582 & 0.87 & -0.5487 & -1.45 \\
\hline Education & $-0.0921 * *$ & -2.78 & 0.0340 & 0.55 & 0.0644 & 0.96 & 0.0296 & 0.16 \\
\hline Farm size & $0.0201 * * *$ & 5.25 & $0.0369 * * *$ & 5.98 & $0.0607 * * *$ & 10.33 & $0.0830 * * *$ & 4.58 \\
\hline Price of Egg & $0.0201 * * *$ & 3.30 & $0.0760 * * *$ & 4.45 & $0.1178 * * *$ & 5.00 & $0.1713 * * *$ & 3.36 \\
\hline Cost of labour & $-0.0144 * * *$ & -3.43 & $-0.0572 * * *$ & -5.6 & $-0.0681 * * *$ & -4.71 & $-0.1369 * * *$ & -4.41 \\
\hline Cost of feed & -0.0016 & -0.45 & 0.0074 & 0.71 & 0.0100 & 0.63 & 0.0260 & 0.82 \\
\hline Cost of DOC & -0.0398 & -0.79 & 0.1970 & 1.29 & $0.6520 * * *$ & 3.01 & 0.7182 & 1.59 \\
\hline Cost of Drugs & $0.3453 * *$ & 2.06 & $1.9487 * * *$ & 4.14 & $4.0574 * * *$ & 6.18 & $4.9863 * * *$ & 3.57 \\
\hline Ogun State & $0.5146^{*}$ & 1.91 & 0.6828 & 1.2 & 0.8741 & 1.36 & 0.5048 & 0.3 \\
\hline Oyo State & 0.1983 & 0.73 & $1.0002 *$ & 1.77 & $1.2711 *$ & 1.88 & $3.3201 *$ & 1.98 \\
\hline Pseudo $\mathrm{R}^{2}$ & 0.54 & & 0.59 & & 0.62 & & & \\
\hline F-statistics & 0.000 & & 0.000 & & 0.000 & & 0.000 & \\
\hline No. of Obs. & 360 & & 360 & & 360 & & 360 & \\
\hline
\end{tabular}

Source: Field Survey, 2018

Note: $* * * * *, *$ significant at $1 \%, 5 \%$ and $10 \%$ respectively.

The coefficient of determination $\left(\mathrm{R}^{2}\right)$ estimated using OLS was 0.879 which implies that $88 \%$ of the variation in farm income was explained by the independent variable included in the model.

The result differs from a priori expectation as the slope coefficient of age of the respondents was positive, though significant across all the models at the $1 \%$ level. This finding implies that a year increase in the age of respondents, leads to an increase in farm income across different quantiles by $0.7 \%, 1.2 \%$ and $1.4 \%$, respectively. It is also observed that as farmer grows older, s/he may have better access to resources and more skills are acquired which may eventually improve s/he income.

Education provides opportunities to have better information, acquires new skill and thus stimulates the mind of the farmers to accept new farming techniques. The coefficient of years of schooling was negatively signed but statistically significant across all quantiles at the $1 \%$ level. The absolute values of this variable increase from lower to upper quantile. However, education of the farmers was hypothesized to be positive, but failed to carry the expected sign. This could be probably meant that farmers can acquire the needed skills in poultry egg farming through extension services, seminar and workshop. This result agrees with the finding of Valerien et al. (2011) that find negative relationship between education and household income in rice-producing areas of Philippines using quantile regression.

Household size had a negative and significant impact on the income of poultry egg farmers as expected at lower and median percentiles. A large family size may mean that more egg will be consumed by house members. The result posits that an additional member to a household, holding other variables constant, leads to income reduction by $0.4 \%$ and $0.1 \%$ at $25^{\text {th }}$ and $50^{\text {th }}$ quantile, respectively. This study concurs with the finding of Okon (2014) that a large family household has negative effect on income. Household size variable was positively related to net income at the upper quantile. This means large scale poultry egg farming requires more hands which can be substituted through family labour or the effect of large family has no significant impact on their income.

As shown in the table, the coefficient of farming experience had a negative significant impact on farm income of egg farmer. This was not however consistent with the $a$ priori expectation of the study. The estimated coefficients, on the average, were $-0.1907,-0.4383$ and 0.5666 respectively, at various chosen quantiles. This result shows that farmers with years of experience are likely to be facing land tenure challenges especially in the urban area where the rate of urbanization is increasing on daily basis compared with the rural areas.

Farmincome is a relative term which can be expressed as a function of farm size, all things being equal. Result also showed that farm size had positive relationship with farm income at $1 \%$ probability level, thereby suggesting that a unit increase in farm size, holding other variables constant, farm income will increase across all chosen quantiles by $0.02 \%, 0.04 \%$ and $0.06 \%$, respectively. This result differs from the findings of Valerien et al. (2011) that farm size was inversely proportional to the household income.

The slope coefficient of price of egg estimated was theoretically consistent with the hypothesis and significant at the $1 \%$ level of probability. The positive association between farm income and the price of egg is an indication that if there is a unit increase in the price of egg, the influence on farm net income will be as high as $0.02 \%$, $0.07 \%$ and $0.11 \%$, respectively across all the quantiles compared to the result obtained from OLS. However, the coefficient of cost of labour, as expected, was inversely proportional to farm income in egg production, thus implying that a $1 \%$ increase in labour wage per hour, all things being equal, farm income will reduce by $0.01 \%$, $0.05 \%$ and $0.06 \%$, respectively across the quantiles. It is observed that the absolute value of labour variable obtained in the study increases as quantile increases. It was observed that the estimate obtained through OLS method appeared to be larger than that of quantile in this study indicating the coefficient produced by OLS is not 
asymptotically efficient. The result from the present study agreed with the study conducted by Oladunni and Fatuase (2014) that cost of labour is inversely proportional to the total revenue derived from backyard poultry farming in Akoko North West LGA of Ondo State, Nigeria.

The result displays in the table showed that cost of feed was negatively related to the income as expected across all quantiles, but this was not statistically significant at $25^{\text {th }}$ and $50^{\text {th }}$ quantiles respectively. At $75^{\text {th }}$ quantile, the cost of DOC was statistically significant at the $1 \%$ level. This, however, means that a $1 \%$ increases in the cost of DOC per bird, assuming other variables in the model are controlled, will induce an increase in the price per crate of egg, hence, this will also translate to an increase in income by $\$ 0.65$.

The slope coefficient of cost of medication was positively signed and statistically significant at the $1 \%$ level all through, implying that a unit increase in the cost of medication will trigger off an increase of $0.34,1.94$ and 4.05 , respectively, in the price of medication. This finding is contrary to the findings of Amos (2006) who found negative relationship between the gross income realised from the production of backyard and cost of vaccination.

The result further showed that dummy variable for farm location was included as a predictor to capture the effect of differences in geographical area on farm income. The location included were Lagos, Ogun and Oyo States, respectively. Lagos State was chosen as the base category. At $25^{\text {th }}$ quantile, the coefficient for Ogun State dummy was 0.5146 . The dummy variable had a positive and significant relationship with the income of poultry egg farmer at the $10 \%$ probability level. The probability of setting up a poultry farm in Ogun State, holding other variables constant, farm income will increase by $0.5 \%$ compared to Lagos State. However, the same variable had no significant impact at median and higher percentiles (e. g $75^{\text {th }}$ quantile) in Ogun State. The effect of owning a poultry farm in Oyo State was found to be positively related to the income of poultry egg farmer at the probability level of $10 \%$ for median and $75^{\text {th }}$ quantile. The coefficient for Oyo dummy at $50^{\text {th }}$ and $75^{\text {th }}$ were 1.0002 and 1.2711 , respectively, indicating if a poultry farm is established in Oyo State compared to Lagos State, farmer's income will commensurately increase by $1.0 \%$ and $1.2 \%$, respectively.

\section{CONCLUSIONS}

This study carried out on the factors affecting the profitability of farmincome among poul try egg farmers in Ondo State, Nigeria showed that poultry egg farmers are still young to cope with the stress associated with poultry egg business. The result concluded that majority of the respondents are male households. This could be due to the fact that male-headed households are always considered to possess more resources and risk-takers compared to women. It was also concluded that majority are married in the study area with a high probability of family labour supply. The mean experience of the farmers was 12 years, and more than half of the respondents were educated. The net income computed from field survey data showed that poultry layer business is profitable in the study area while quantile regression result showed that age of the respondent, farm size, price of egg, cost of drugs and farm location had positive significant impacts on farm income at one quantiles or the other. However, education of respondents, farmer's experience, household size, costs of labour, feed and day-old-chicks were identified as factors that had negative but significant influence on poultry farm income across the quantiles. Based on the findings of this study, the following recommendations are given as:

(i) Governments at all levels should encourage youths to embrace poultry business in order to reduce poverty and unemployment in the country;

(ii) Government should formulate policy that will stimulate competitiveness in poultry industry;

(iii) Also, policy that will increase farmers' profit and reduce input prices should be put in place by the policy maker;

(iv) Efficient extension services should be put in place to provide timely delivery of poultry egg information to the farmers; and

(v) Access to credit facility in the country should be improved upon since capital is one of the major obstacles confronting poultry egg farmers.

\section{Acknowledgements}

Authors are grateful to extension workers in Lagos States Ministry of Agriculture and Poultry Association of Nigeria for their contributions to this work during data collection.

\section{REFERENCES}

ADEBIYI, M. A. (2000). Economic Analysis of Egg production in Ondo State, B. Tech Project, Department of Agricultural Economics and Extension, FUT, Akure. Unpublished.

ADENE, D. F., \& OGUNTADE, A. E. (2006): The Structure and Importance of the Commercial and VillageBased Poultry Systems in Nigeria/ FAO,

ADEPOJU, A. A. (2008). Technical Efficiency of Egg Production in Osun State. International Journal of Agricultural Economics and Rural Development IJAERD, Pp 7-14

ADEYONU, A. G., OYAWOYE, E. O., OTUNAIYA, A. O., \& AKINLADE, R. J. (2016). Determinants of poultry Farmers' Willingness to Participate in National Agricultural Insurance Scheme in Oyo State, Nigeria. Applied Tropical Agriculture, A publication of the School of Agriculture and Agricultural Technology, The Federal University of Technology, Akure, Nigeria. Volume 21, No 3, pp 55-62,

ADF. AFRICAN DEVELOPMENT FUND (2003). Community-based Agricultural and Rural Development Project Appraisal Report. Agricultural and Rural Development Department, Central and West Regions, Federal Republic of Nigeria. 1-9

AFOLAMI, C. A., ALADEJEBI, O. J. \& OKOJIE, L. O. (2013). Analysis of Profitability and Constraints in Poultry Egg Farming Under Battery Cage and Deep Litter 
Systems in Ogun State, Nigeria: A Comparative Study. IJAFS 4 (1\&2). pp 581-595.

AGBOOLA, S. A. (1979). An Agricultural Atlas of Nigeria, Oxford University Press, Nigeria. Pp248.

ALABI, R. A., \& ISAH, A. O. (2002). Poultry Production Constraints. The Case of Esan West Local Government Area of Edo State, Nigeria: African Journal of Livestock Extension 1(1), (2002) 58-61. https://www.ajol.info/index.php/ajlex/article/view/115 AMOS, T. T. (2006). Analysis of Backyard Poultry Production in Ondo State, Nigeria. International Journal of Poultry Science 5(8), 247-250. DOI: 10.3923/ijps.2006.247.250

ASHAGIDIGBI, W.M., SULAIMON, S.A., \& ADESIYAN, A. (2011). Technical efficiency of egg production in Osun State. International Journal of Agricultural Economics and Rural Development, 4 (6):120-131. DOI: 10.3923/aj.2011.124.130

ASL. AFRICA SUSTAINABLE LIVESTOCK (2018). Livestock production systems spotlight Nigeria. FAO, Rome, Italy.

CADE, B. S., TERRELL, J. W., \& SCHROEDER, R. L. (1999). Estimation Effects of Limiting Factors with Regression Quantiles. Ecology 80: (1999) 311-23. DOI: 10.1890/0012-965(1999)080[0311:EEOLFW]2.0.CO;2

DE JANVRY, A., SADOULET, E., \& ZHU, N. (2005). The Role of Non-Farm Income in Reducing Poverty and Inequality in China. CUDARE Working Paper 1001, University of California, Berkeley. https://escholarship.org/uc/item/7ts2z766

EMOKARO, C. O., \& EMOKPAE P. O. (2014). Technical Efficiency and Production Elasticity of Broiler Producers in Edo State, Nigeria, Applied Tropical Agriculture, Vol. 19, No 1, Pp 59-69. www.futa.edu.ng/journal/home/paperd/383/10/11

EVBUOMWAN, G. O. (2005). Empirical Analysis of Cost and Returns to Commercial Table Egg Production in Lagos State. Farm Management Association of Nigeria Conference, Asaba, Nigeria, Research and Statistics Department, Central Bank of Nigeria, Pp. 27-37

KOENKER, R. W., \& BASSETT, G. W. (1982). Robust Tests for Heteroscedasticity based on Regression Quantiles, Econometrica, Vol. 50, pp. 43-61. DOI: $\underline{10.2307 / 1912528}$

LASEINDE, E. A. O. (1982). Technical Guide to Poultry Production Division of Agricultural Colleges, Newsletter, Vol. 1: 4, (14-18), Ahmadu Bello University, Zaria, Nigeria.

NASS. NATIONAL AGRICULTURAL SAMPLE SURVEY (2011). National bureau of statistics/ federal ministry of agriculture and rural development collaborative survey on national sample survey 2010/2011 http://www.premiumtimesng.com

NYANTAKYI, K. A., PEIRIS, B. L., \& GUNARATNE, L. H. P. (2015). Analysis of the Interrelationships between the Prices of Sri Lankan Rubber, Tea and Coconut Production Using Multivariate Time Series. Advances in Economics and Business 3.2 (2015) 50 - 56. DOI: 10.13189/aeb.2015.030203.

NBS. National Bureau of Statistics. (2018). National Bureau of Statistics Report 2018
NPC. National Population Commission (2006). Analysis of Nigeria 2006 Census Result, NPC, Abuja, Nigeria.

OJO, S. O. (2003). Productivity and Technical Efficiency of Poultry Egg Production in Nigeria. International Journal of Poultry Science, 2(6); 459-46. DOI: 10.3923/ijps.2003.459.464

OKON, U. E. (2014). Assessment of Income Generating Activities among Urban Farm Households in South-South, Nigeria, University of Nigeria Nsukka, Virtual Library PhD Thesis (Unpublished).

OKORJI, E. C. (1988). Women and Rural Development Strategies for Sustaining Women Contribution in Rural Households of Anambra State, Nigeria. Working paper, No 166. Women in International Development, Michigan state University, pp 16.

OKUNMADEWA, F. (1999). Livestock Industry as Tool for Poverty Alleviation. Tropical Journal of Animal Science, 2(2): pp 21-30

OLADUNNI, M. E., \& FATUASE, A. I. (2014). Economic analysis of backyard poultry Farming in Akoko North West Local Government Area of Ondo State, Nigeria. Global Institute for research and Education ISSN: $\quad 2319-5584, \quad$ Vol. 3(1), 141-147. https://www.longdom.org/articles/economic-analysis-ofbackyard-poultry-farming-in-akoko-north-westlocalgovernment-area-of-ondo-state-nigeria.pdf OLUYEMI, J. A. \& ROBERTS, F. A. (1979). Poultry Production in the Warm Wet Climate. Macmillan Press Ltd London, $197 \mathrm{p}$.

OMOTOSHO, O. A., \& OLADELE, A. A. (1988). Management Problems in Large Scale Poultry Business in Nigeria. Farm Management Nigerian Journal, Vol.3: pp, 27-35

SAHEL. Sahel Capital (Mauritius) Limited (2015). An Assessment of the Nigerian Poultry Sector. Vol. 11, Pp. 13. http://sahelcp.com/wp-content/uploads/2016/12/SahelNewsletter-Volume-11.pdf

VALERIEN, O. P., JOYCE, S. L., THELMA, R. P., \& JUSTIN, D. M. (2011). Determinants of Household Income: A Quantiles Regression Approach for Four RiceProducing Area in the Philippines. Asian Journal of Agriculture and Development, Vol. 9, No. 2, pp. 65-76. DOI: 10.22004/ag.econ.199102

WORLD POULTRY (2013). Feed Prices Stunt Poultry Industry in Nigeria. Poultry World, Mar 5, 2013. 